\title{
INTERNAL ENVIRONMENTAL POLLUTION PERSPECTIVE HADITH
}

\author{
Abdul Fattah ${ }^{1}$ \\ Ambo Asse ${ }^{2}$ \\ A. Qadir Gassing ${ }^{3}$ \\ Zulfahmi ${ }^{4}$ \\ Alauddin State Islamic University Makassar, Indonesia ${ }^{1,2,3,4}$ \\ emailkorespondensi@gmail.com
}

\begin{abstract}
Environmental pollution in the perspective of the Prophet's hadith. what is meant here is a study of the hadith of the Prophet. which discusses environmental pollution with 3 issues that will be discussed 1) how is the quality of the hadith about environmental pollution, 2) how is the content of the hadith about environmental pollution both formally and substantially, and 3) what are the implications of the meaning of the hadith about environmental pollution and efforts prevention. The type of research used is descriptive with a rationalistic style, namely describing the quality, validity, and analysis of the traditions of the Prophet Muhammad, both in the aspect of the sanad and its matan. This research includes source studies (text review) because the emphasis is more on library research. In the research library, data is collected by quoting, adapting, and analyzing using content analysis on representative literature that has relevance to the problems discussed, then reviews and concludes. The results of research on environmental pollution in the perspective of the Prophet's hadith; First, the hadith of the Prophet (saw) related to environmental pollution has authentic quality. Second, a) the essence of environmental pollution is the occurrence of changes in a substance (water, soil or air) due to the inclusion of other components in it that can affect the quality of the environment (water, soil or air). b) forms of environmental pollution and their impacts include 1) prohibition of urination in stagnant water as a form of environmental pollution of water, 2) prohibition of defecating in public places, and water sources as a form of soil and water pollution, 3) prohibition of elevating buildings that block surrounding housing from clean air and prohibition of directing dirty air to it as a form of air pollution. Third, solutions to environmental pollution, namely; 1) Go green 2) Go clean, and 3) Environmental conservation. Based on the results of the study, it is recommended that UIN Alauddin Makassar establish a Center for Environmental Studies in order to give birth to Environmental Fiqh (fiqh of land, water and air) and that Government agencies engaged in the field of Environment in an effort to overcome environmental pollution to strengthen existing regulations even need to made new regulations in an effort to preserve the environment with a religious science approach. 3) prohibition of elevating buildings that block surrounding housing from clean air and prohibition of directing dirty air to it as a form of air pollution. Third, solutions to environmental pollution, namely; 1) Go green 2) Go clean, and 3) Environmental conservation. Based on the results of the study, it is recommended that UIN Alauddin Makassar form a Center for Environmental Studies in order to give birth to Environmental Fiqh (fiqh of land, water and air) and that Government agencies engaged in the field of Environment in an effort to overcome environmental pollution to strengthen existing regulations even need to made new regulations in an effort to preserve the environment with a religious science approach. 3) prohibition of elevating buildings that block surrounding housing
\end{abstract}


from clean air and prohibition of directing dirty air to it as a form of air pollution. Third, solutions to environmental pollution, namely; 1) Go green 2) Go clean, and 3) Environmental conservation. Based on the results of the study, it is recommended that UIN Alauddin Makassar form a Center for Environmental Studies in order to give birth to Environmental Fiqh (fiqh of land, water and air) and that Government agencies engaged in the field of Environment in an effort to overcome environmental pollution to strengthen existing regulations even need to made new regulations in an effort to preserve the environment with a religious science approach. 1) Go green 2) Go clean, and 3) Environmental conservation. Based on the results of the study, it is recommended that UIN Alauddin Makassar form a Center for Environmental Studies in order to give birth to Environmental Fiqh (fiqh of land, water and air) and that Government agencies engaged in the field of Environment in an effort to overcome environmental pollution to strengthen existing regulations even need to made new regulations in an effort to preserve the environment with a religious science approach. 1) Go green 2) Go clean, and 3) Environmental conservation. Based on the results of the study, it is recommended that UIN Alauddin Makassar form a Center for Environmental Studies in order to give birth to Environmental Fiqh (fiqh of land, water and air) and that Government agencies engaged in the field of Environment in an effort to overcome environmental pollution to strengthen existing regulations even need to made new regulations in an effort to preserve the environment with a religious science approach.

Keywords: Environmental pollution; The Prophet's Hadith Perspective

\section{INTRODUCTION}

The Hadith of the Prophet as the second source of Islamic teachings after the Qur'an not only provides explanations related to legal issues nor only applies during the time of the Prophet, but covers all aspects of human life and is valid until the end of time, both in this world and in the hereafter.

The presence of the Prophet's hadith in every era of human civilization is required to truly be able to answer every problem of the people as a dialectical consequence between the development of the times on the one hand and the demand to continue to adhere to religious principles on the other. And not the other way around, hadith becomes a barrier to any progress of human civilization, judging it as heresy, a source of division, stagnation and decline. Even at a practical level, the Prophet's hadith is often a formal legality against "oppression" and "oppression" of one group against another. Whereas as a source of Islamic teachings that are divine in nature, they should bring benefit and mercy to all people and even to the whole of nature. ${ }^{1}$

Al-Qur'an and hadith serve as guidance for Muslims in particular and as a mercy for the whole world, not only serve as a normative basis that skyrockets but how these teachings can be grounded in the midst of society. Mankind in facing the challenges and problems faced by making new formulations as a solution to existing problems. There are

${ }^{1}$ Arifuddin Ahmad, Metodologi Pemahaman Hadis; Kajan Ilmu Ma'ānì al-Hadis (Cet. 2; Makassar: Alauddin University Press, 2012), h. 1-2. 
many problems faced by mankind, especially Muslims, which until now have not received full attention, such as problems of poverty, ignorance, underdevelopment, mental illness, the environment and others. Problems that have not become a serious concern for Muslims, especially in Indonesia, include environmental problems.

Talking about the environment means getting involved in a very broad problem, which includes all aspects related to the human environment, among which, the universe with all its facilities is an environment that affects the environment, both living things and other objects. Every creature created by Allah swt., has dependence on one another. Humans can carry out their lives well with the involvement and participation of other creatures, such as plants, animals and micro-organisms. ${ }^{2}$

Likewise, Allah swt., made humans from soil, then they were assigned to prosper in the sense of maintaining, managing, managing and utilizing them properly and appropriately in order to build a better life (advance and prosperity). ${ }^{3}$ Allah says in QS Hūd/11:61.

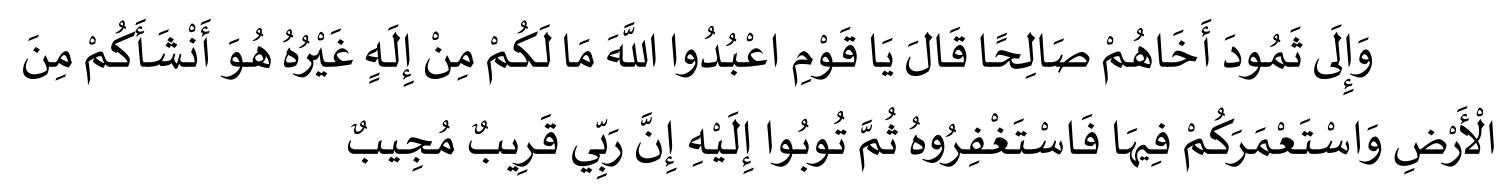

Terjemahannya:

"And to Thamud [We sent] their brother Salih. He said, "O my people, worship Allah; you have no deity other than Him. He has produced you from the earth and settled you in it, so ask forgiveness of Him and then repent to Him. Indeed, my Lord is near and responsive."

Caring for the environment is actually for the benefit of the human species itself. The prohibition of making environmental damage has implications for the necessity of protecting it not only for ourselves but further for our fut ure generations.

In various regions of the world, environmental issues are an issue that attracts a lot of attention. Especially in Indonesia, environmental problems are problems that have not been resolved, especially how to overcome various forms of pollution that occur, whether it occurs in the land environment or the water environment. Therefore, the Government of Indonesia issued many regulations and laws. Among these laws and regulations, such as Law of the Republic of Indonesia Number 32 of 2009 concerning Environmental Protection and Management, Government Regulation of the Republic of Indonesia Number 19 of 1999 concerning Control of Marine Pollution and/or Destruction, Law of the Republic of Indonesia Number 18 of 19992008 concerning Waste Management, and other laws and regulations.

This research is included in the scope of the environment, namely: First, the land environment (land) with one of the hadith themes, namely the prohibition of defecating on public roads and shelters, Second, the water environment with one of the hadith themed on the prohibition of urinating in calm water. flooded, Third, the air environment 1997), h. 51.

${ }^{2}$ Otto Sumarwoto, Ekologi Lingkungan Hidup dan pembangunan (Cet. VII; Jakarta: Djambata,

${ }^{3}$ Muhammad Suryani dkk., Lingkungan Sumber Daya Alam dan Kependudukan dalam Pembangunan (Jakarta: UI-Press, 1987), h. 3.

${ }^{4}$ Departemen Agama RI, Al-Qur'an dan Terjemahnya, 
with the hadith of the Prophet. about the rights of neighbors in which it states the prohibition of elevating the building without the neighbor's permission and the prohibition of sending dirty air to neighbors. Fourth, environmental preservation as a form of overcoming environmental pollution with the hadith about tree planting as one of the basics. ${ }^{5}$

Based on the Prophet's instructions, in relation to the environment, the researcher wants to conduct more in-depth research and study of the hadiths related to the environment, both in the aspects of pollution, the impact of pollution, and the preservation of plants as an effort to overcome environmental pollution.

\section{LITERATUR REVIEW}

Hadith is believed by the Muslim community as the second source of Shari'ah which is subordinate to the Qur'an. Unlike the case with the Qur'an which is believed without exception as a revelation of Allah swt. which was revealed to the Messenger of Allah, which has been written since the Messenger of Allah. is still alive and has come to us today with a process of narration that takes place mutawātir (qat'i wurud) and whose contents are qat'i al-dalalah and zanni al-dalalah. Meanwhile, the process of transmitting hadith is mostly on a weekly basis (zanni al-wurud) and very rarely is mutawatir (qat'i wurud). That is a strong reason so that it becomes something that should be studied or researched.

Meanwhile, according to Syuhudi Ismail, there are at least 6 (six) factors that make hadith research very important, namely (1) hadith as a source of Islamic teachings; (2) not all hadiths were written at the time of the Prophet; (3) there have been various falsifications of hadith; (4) the process of collecting hadith which takes a long time; (5) a large number of hadith books with various compilation methods; and (6) there has been a meaningful transmission of hadith.

In conducting research on hadith, there are (2) two parts that become the object of research, namely a series of narrators who convey the history of hadith known as the sanad of hadith and the material or matan of the hadith itself. From the research on the object of the hadith, the results of the research if related to the sanad are the possibility of mutawātir and ahad and in terms of quality the possible results are sahịị, hasana or da'if, and before continuing the research First, the quality status of the sanad must be clear. If the status of the sanad is not valid, then that is enough, but if it is valid, the research is continued on the subject. As for if it is related to the matan of hadith, the possible result is to avoid syaz' and 'illat or it may contain syaz' and 'illat.

After understanding the (content) of the Prophet's hadith, it is necessary to carry out a development analysis which is expected to be able to provide the right formulation and in accordance with the context of the current problems faced by Muslims in solving various existing problems based on the development of science and technology that has been created by humans themselves progress of civilization. This study is intended to examine and examine the hadith which is the basis, reason or evidence of the ulama in establishing a law on environmental issues related to environmental pollution and efforts to overcome them.

${ }^{5}$ A. Warson Munawwir, Al-Muanawwir: Kamus Arab-Indonesia, (Cet. 14; Surabaya: Pustaka Progressif, 1997), h. 1001. 
In conducting studies and research on the thematic hadith studies, the steps taken include, takhrij hadith activities to explore traditions related to the hadith research themes which are then classified based on ontological, epistemological and axiological studies of hadith themes.

The next step is to critique the hadith of the hadith both in the aspect of the sanad and the matan of the hadith to determine the quality based on the authenticity of the sanad and the matan of the hadith, of course by using all the elements of assessment, both major and minor rules in determining the validity of the studied hadith. ${ }^{6}$

Through the steps carried out critically and critically so that the hadith about environmental pollution can be understood textually, intertextually and contextually both in its ontological, epistemological and axiological aspects.

\section{METHOD}

The type of research used is descriptive with a rationalistic style, namely describing the quality, validity, and analysis of the traditions of the Prophet Muhammad, both in the aspect of the sanad and its matan. This research includes source studies (text review) because the emphasis is more on library research. In library research, data is collected by quoting, adapting, and analyzing using content analysis on representative literature that has relevance to the problems discussed, then reviews and concludes.

\section{RESEARCH RESULTS AND DISCUSSION}

In this section, it will be explained related to the analysis of the meaning of hadith on environmental pollution and its solutions.

\section{A. Verses of the Qur'an about the Prohibition of Damaging the Environment}

Environmentin the study of the Qur'an, there are several verses that provide instructions related to the prohibition of damaging the environment, including QS. AlBaqarah/2: 30 .

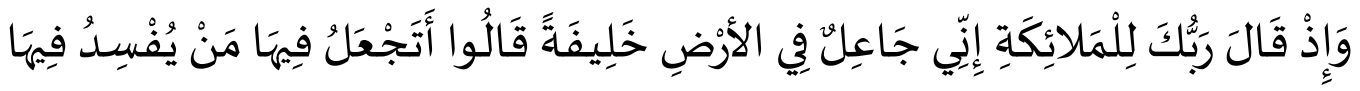



Terjemahnya:

"And (mention, O Muhammad), when your Lord said to the angels, "Indeed, I will make upon the earth a successive authority." They said, "Will You place upon it one who causes corruption therein and sheds blood, while we declare Your praise and sanctify You?" Allah said, "Indeed, I know that which you do not know."7

${ }^{6}$ Ambo Asse, Studi Hadis Maudhu'i ; sebuah kajian metodologi holistik (Cet. 1; Makassar: Alauddin University Press, 2013), h. 12-13. 5.

${ }^{7}$ Departemen Agama RI, Al-Qur'an dan Terjemahnya(Jakarta: Syamil Cipta Media, 2005 M), h. 



What is meant is that the angels ask Allah that they are always praising and exalting Him and also that the angels do not like any immorality that will occur as previously sent from among the jinn but they have disobeyed Allah swt. ${ }^{8}$ by committing bloodshed and killing each other. In a narration, Ibn Abbas said: that the jinn were created from a blazing fire that emanated from among the angels. as mentioned in the Qur'an min mārijin min nār, which comes from a blazing fire. ${ }^{9}$ as they (the angels) know that in man created from the noble land from the light of Muhammad there is in him the lust of ammarah bissu' (a soul inclined to evil). ${ }^{10} \mathrm{This}$ is also explained in QS. AlSyūrā/42: 30, QS. Al-Rūm/30: 41, and QS. Al-Qașaș/28.

\section{B. Hadith about the Nature of Environmental Pollution}

1. Hadith about the levels and criteria for water containing najis

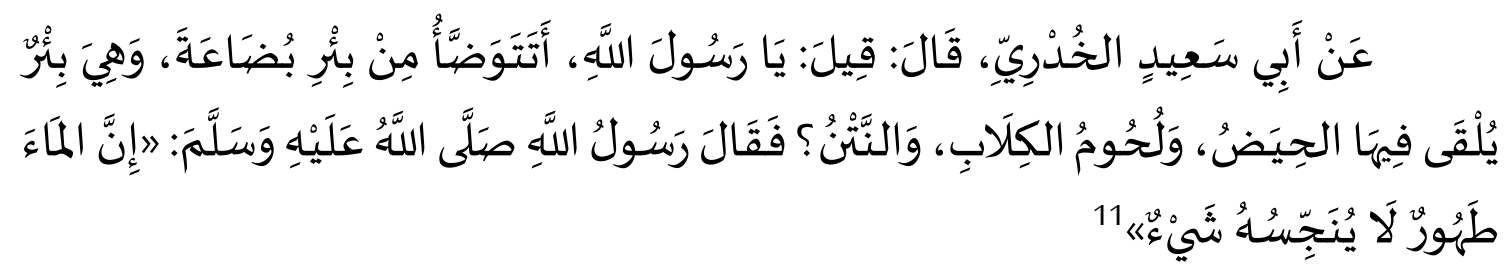

\section{Hadith Syarah}

ParaThe scholars in providing an explanation of the above hadith have different views. They have different views on the sanctity of water if the water has been mixed with najis but does not change any of the properties of the water then the water is still pure whether the amount is small or large. They determine the impurity of a water mixed with najis if the najis causes a change in one of the properties of water (taste, smell, and or color). ${ }^{12}$

\section{Hadith about Sources, Forms of Environmental Pollution and Their Impacts}

1. Hadith about the Prohibition of Urinating in Stagnant Water

\footnotetext{
${ }^{8} \mathrm{Abū}$ al-Hasan al-Majāsyi'i al-Akhfasyi, Ma'ānī al-Qur'ān, has been confirmed by Hudā Mahmūd Qurā'ah (Cet. 1: Cairo: Maktabah al-Khāniji, 1411 H./1990 AD), Juz 1, p. 62.

${ }^{9}$ Abu Ja'far al-Ṭabari Muhammad bin Jarī bin Yazīd bin kas̄īr bin Gālib al-Āmili, Jāmi' al-Bayān fĩ Ta'wilal -Qur'an, confirmed by Ahmad Muhammad Syākir (Cet. 1; Muassasah al-Risalah, 1420 H./ 2000 AD, tt), Juz I, p. 455.

${ }^{10}$ Abū Muhammad Sahl bin Abdullah bin Yunus bin Rafi' al-Tustarī, collected by Abū Bakr Muhammad al-Baladi and confirmed by Muhammad Bāsil 'Uyūun al-Saud (Cet. 1; Bairut: Dā r al-Kutub al-'Ilmiyah, 1423 H.), p. 21.

${ }^{11}$ Al-Tarmidzi, Sunan al-Tarmidzì, Juz I, h. 95.

${ }^{12}$ Muhammad bin Ismā'il bin Șilah bin Muhammad al-Ḥasanī, Subul al-Salām (Dār al-Ḥadis, tt, t.th.), Juz I, h. 22.
} 


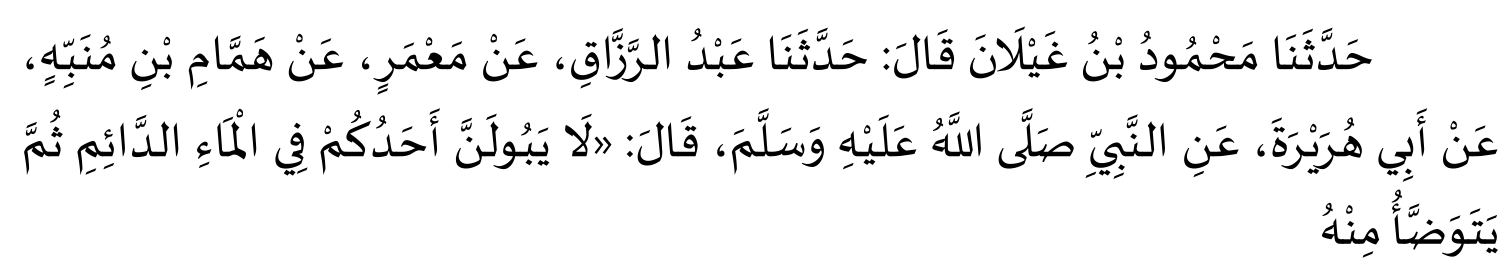

\section{Syarah Hadith}

The above hadith implicitly discusses prohibiting urination or urination in stagnant/quiet water. Even though the hadith has various editorials, it has the same scope of meaning, as has been stated in the previous chapter. The prohibition of bathing in the argument shows a harsh law as is the prohibition of urinating (peeing) unless bathing in it does not make the body/body unclean. Because the body of a believer is not unclean while the urine contains najis. ${ }^{13}$

From all the views of scholars that have been stated above, the author concludes that the hadith is about the prohibition of urinating or urinating in stagnant/quiet water. Even though these hadiths have various editorials, they have the same scope of meaning with each other. This shows that the hadith is narrated in meaning (hadith bil ma'na). As for the meaning of the content, there are at least three, namely; first, the prohibition of ablution in unclean water; second, the adab of purification (ablution) from urine contained in water that does not flow, with the belief that urination will continue in it because among several sunnahs of the Prophet, it is a matter of cleanliness and good manners/morals that must be indicted to the wider community; Third,

The discussion of the hadith mentioned above, namely the prohibition of urinating in stagnant/quiet water as well as the three groups who were cursed for defecating can be understood that the Prophet. has given instructions to humans, especially to their people to always maintain the cleanliness of the environment, be it the environment on land, water and air. Therefore, if humans do not pay attention to their environment or even do damage, it will certainly have an impact on the occurrence of various forms of environmental pollution as in the two hadiths. If the two hadiths are not implemented in relation to the prohibition to perform these actions and even these actions occur continuously, it will certainly have an impact on the occurrence of environmental pollution, whether it is pollution on land, pollution on water,

\section{Hadith about Solutions to Environmental Pollution}

\section{Hadith about Planting Trees}

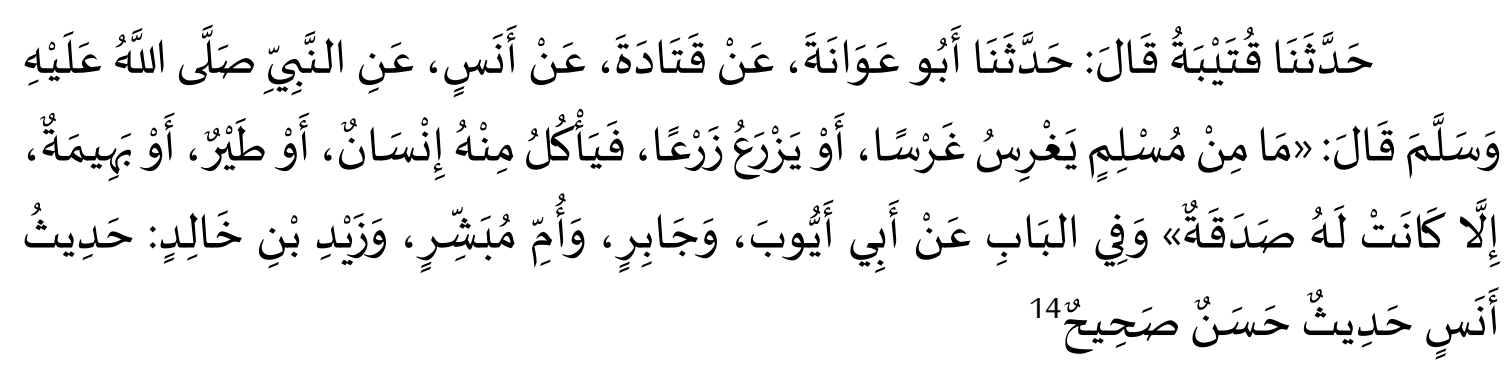

\footnotetext{
${ }^{13}$ Abū Sualiman Hammad bin Muhammad bin Ibrahìm bin Khațtāb al-Bastī al-Khațīàbì, Ma'ālim al-Sunan (Cet. I; Halab: Al- Maṭba'ah al-'Ilmiyah, 1351 H./1932 AD), Juz I, p. 38. 658.

${ }^{14}$ Muhammad bin 'Isā bin Saurah bin Musā bin al-Dahhāk al-Tirmizìi, Sunan al-Tirmizìi, Juz 3, h.
} 


\section{Syarah Hadith}

In another hadith it is mentioned about the virtue of planting trees. Although different editors, but have the same scope of meaning. The Prophet's Conversation with a womanār which becomes asbāb al-wurŪd hadith about the recommendation to plant ${ }^{15}$ trees, implicitly or explicitly provide motivation and rewards for those who plant or carry out reforestation. This became a necessity when looking at the Arab geographical context at that time. From the sociological aspect, the recommendation for reforestation teaches us to do good in the social sphere, namely prioritizing the public interest. Islam not only teaches ritual-worship alone but is highly recommended as well as social worship.

Yusuf al-Qaradawi gave reasons for the recommendation to plant trees and plants as an effort to reforest. There are two basic considerations of reforestation efforts. The first consideration is the consideration of benefits and the second consideration is the aspect of beauty (aesthetic). ${ }^{16}$ The concept contained in the hadith of the virtue of planting and the reward for those who plant it is to harmonize between farming, or all human activities, and reforestation. Thus, these hadiths can be a reference and concept for all parties, especially the government, to make reforestation a means for further environmental comfort.

In this section, it will be explained related to the implications of the meaning of hadith regarding environmental pollution and its solutions

Environmental problems that arise in one place can certainly affect the environment around it. So it needs an awareness that is grown, especially in the form of environmental ethics to overcome environmental problems and environmental sustainability. ${ }^{17}$ Yusuf al-Qardhawi, for example, tries to give the concept of environmental preservation in a qur'ani way. In observing the environment, he uses the term al-bi'ah, while maintenance uses the term al-ri'ayah, so that environmental care is known as ri'ayah al-bi'ah, which has the meaning of terminology as an effort to maintain from the side of its existence and absence. or from the positive and negative sides so that it requires the maintenance of the environment towards efforts that can develop, improve, and preserve it. Thus the maintenance of the environment from negative attitudes and behavior has the implication that the preservation of the environment from damage, pollution and anything that can be harmful. ${ }^{18}$

Ecologically, environmental preservation is an ecological necessity that cannot be negotiated by anyone at any time. Therefore, the preservation of the environment must not be done, it must be done by humans. As for spiritually, Islamic fiqh, Allah swt., has complete ecological concern. At least these two approaches provide a balance of mindset that a good environment in the form of abundant natural resources given by

\footnotetext{
${ }^{15}$ Ibnu Hajar al-'Asqalani, Fath al-Bān̄ fi Syarh șaḥịh al-Bukhārn̄, Juz VII, h. 167.

${ }^{16}$ Y ūsuf al-Qaraḍawi, Islam Agama Ramah Lingkungan. terj. Abdullah Hakam Shah, h. 83-85.

${ }^{17}$ Muh. Aris Marfai, Pengantar Etika Lingkungan dan Kearifan Lokal, (Cet. 2; Yogyakarta: Gajah Madah University Press, 2013), h. 19-20.

${ }^{18}$ Y usuf al-Qardhawi, Islam Ramah Lingkungan, diterjemahkan oleh Abdullah Hakam (Jakarta: Pustaka Kautrsar, 2002 M.), h. 3.
} 
Allah swt., to humans will not be sustainable and recover (recovery) if there is no human intervention. ${ }^{19} \mathrm{As}$ in QS. Al-Ra'd verse 11.

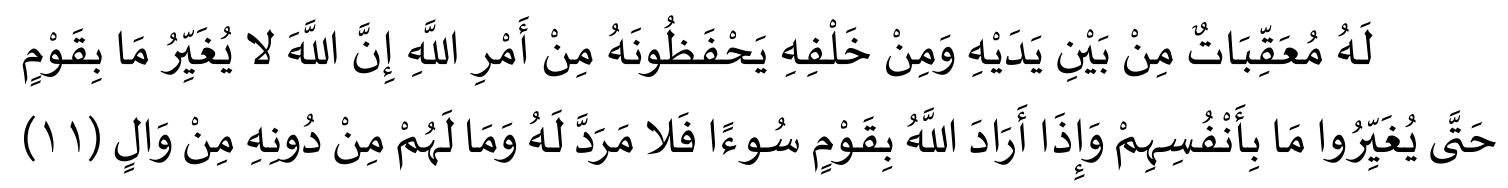

Terjemahnya:

"For each one are successive [angels] before and behind him who protect him by the decree of Allah. Indeed, Allah will not change the condition of a people until they change what is in themselves. And when Allah intends for a people ill, there is no repelling it. And there is not for them besides Him any patron." 20

Muslims always believe not to fall into a second mistake. Incredible events that have been experienced by humans recently, such as natural disasters such as tsunamis, earthquakes, air pollution, water and soil pollution and the greedy nature of entrepreneurs by clearing tropical forests through illegal logging activities, as well as a series of other forms of environmental damage, must be a very valuable lesson. This is confirmed by Allah swt., QS. Al-Hashr verse 2.

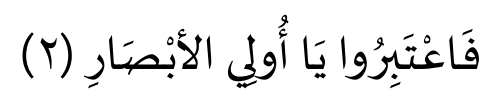

Terjemahnya:

"So take warning, O people of vision.",21

Management of environmental sustainability is a form of preventive action against environmental changes due to human activities and activities. With this management, efforts will be made to minimize air, water and soil pollution, as well as other pollution due to the role of the environment as a mediation against changes and damage as well as environmental pollution.

There are several efforts that can be done in preventing and overcoming environmental pollution based on the instructions of the Prophet, namely;

a. The Green Movement (go green) The current urban climate has undergone a striking change under the influence of the density and centralization of urban activities where the assessment of urban areas will be reviewed in a certain and separate way from the regional climate, such as the effect caused by the lack of urban green space on ecology. The city, especially in relation to the climate of air, soil, water, is so influential that its constituent and constructive elements actually undergo changes in the urban environment.

b. Cleanliness Movement (Go Clean) Religion from an early age instructs its adherents to live cleanly, because after all cleanliness is a form of

\footnotetext{
${ }^{19}$ Arif Sumantri, Environmental Health \& Islamic Perspective (Cet. 1: Jakarta: Kencana, 2010), p. 286.

${ }^{20}$ Departemen Agama RI, Al-Qur'an dan Terjemahnya, h. 250.

${ }^{21}$ Departemen Agama RI, Al-Qur'an dan Terjemahnya, h. 545
} 
beauty, while beauty is something that is loved by Allah. However, cleanliness is not only understood as an activity of removing dirt, keeping dirt from polluting the environment, it is also a form of the environment whose value is more noble than just throwing dirt.

c. Environmental Conservation, Environment within the framework of ecosystems and ecology is a dynamic space with various kinds of interactions and a series of processes that take place in it. Environmental dynamics can be interpreted in terms of positive dynamics such as the sustainability of conservation and biodiversity and in terms of negative dynamics such as the occurrence of damage, environmental degradation and natural disasters.

d. Meanwhile, the sustainability of conservation efforts that create positive dynamics on the environment, one of which is the practice of local wisdom that appears in local communities. Local wisdom is an important part of the pillars of environmental conservation. Environmental ethics is part of real natural disasters that often have an impact in the form of losses from both a material and ecological perspective. Thus discussing disaster as an element in environmental dynamics becomes very relevant.

\section{CONCLUSION}

Based on the results of research that has been carried out related to the environment from the perspective of the Prophet's hadith, it can be concluded that: 1 . The quality of the hadith about environmental pollution which is the object of the study has met the requirements for the validity of the sanad and the matan of the hadith, because three elements of the validity of the sanad have been fulfilled., that is, the chain is continuous and the narration is 'adil and dābit. However, the hadith regarding the rights of neighbors, which contains the form of air pollution is daif because one of the narrators is judged to be a da'if person. Meanwhile, in terms of eyes, it has been free from syäż, that is, it does not conflict with the arguments of the Qur'an, does not conflict with more authentic hadiths, does not conflict with historical facts, and does not contradict with common sense, And free from 'illah although in terms of pronunciation of matan there are some differences, but these differences do not affect the meaning and substance of the hadith so that it can be concluded that the hadith is sahị status. 2 . Hadith of the Prophet. and its content in relation to environmental pollution includes several hadiths, namely; a) Hadith regarding the sanctity/cleanliness of water against najis as the essence of environmental pollution and its components, b) Hadith concerning the prohibition of urinating in stagnant water as a form of water pollution, c) Hadith concerning Allah's curse on people who make intentions in public places as a form of water pollution., land and air), d) hadith about the rights of neighbors as a form of air pollution. 3. Efforts to prevent pollution and environmental damage are partly due to the stipulation of regulations in the form of laws, government regulations and presidential and ministerial decisions related to the environment, while based on the instructions of the Prophet's hadith, there are at least four efforts to prevent pollution and environmental damage that can be done, that is; Planting trees (go green), maintaining environmental cleanliness and managing waste (go clean), and environmental conservation. 


\section{BIBLIOGRAPHY}

Abdullah, Hamid Al-Humaidi, Bid'ah-Bid'ah Kubur, terj. Abdul Rosyad Shiddiq Jakarta: Pustaka Al-Kautsar, 2003.

A. Warson Munawwir, Al-Muanawwir: Kamus Arab-Indonesia, Cet. 14; Surabaya: Pustaka Progressif, 1997

Abu Ja'far al-Ṭabarī Muhammad bin Jarīr bin Yazìd bin kas̄īr bin Gālib al-Āmili, Jāmi' al-Bayān fĩ Ta’wilal-Qur'an, ditahqiq oleh Ahmad Muhammad Syākir Cet. 1; Muassasah al-Risalah, 1420 H./ 2000 M.

Abū al-Hasan al-Majāsyi'‘̄ al-Akhfasyi, Ma'ānì al-Qur'ān, telah ditahqiq oleh Hudā Mahmūd Qurā'ah Cet. 1: Kairo: Maktabah al-Khāniji, 1411 H./ 1990 M.

Abū Muhammad Sahl bin Abdullah bin Yunus bin Rafí' al-Tustarì, dikumpulkan oleh Abū Bakr Muhammad al-Baladì dan ditahqiq oleh Muhammad Bāsil 'Uyun alSaud Cet. 1; Bairut: Dār al-Kutub al-'Ilmiyah, 1423 H.

Abū Sualiman Hammad bin Muhammad bin Ibrahīm bin Khatțāb al-Bastī al-Khațtābì, Ma'ālim al-Sunan Cet. I; Halab: Al-Maṭba'ah al-'Ilmiyah, 1351 H./1932 M.), Juz I, h. 38 .

Al-Tarmidzi, Sunan al-Tarmidzì, Juz I, h. 95.

Ambo Asse, Studi Hadis Maudhu'i ; sebuah kajian metodologi holistik Cet. 1; Makassar: Alauddin University Press, 2013

Arif Sumantri, Kesehatan Lingkungan \& Perspektif Islam Cet. 1: Jakarta: Kencana, 2010)

Arifuddin Ahmad, Metodologi Pemahaman Hadis; Kajan Ilmu Ma'ānì al-Hadis Cet. 2; Makassar: Alauddin University Press, 2012

Departemen Agama RI, Al-Qur'an dan Terjemahnya Jakarta: Syamil Cipta Media, 2005 $\mathrm{M}$

Ibnu Hajar al-‘Asqalani, Fath al-Bārī fĩ Syarḥ șaḥịh al-Bukhārī, Juz VII

Muh. Aris Marfai, Pengantar Etika Lingkungan dan Kearifan Lokal, Cet. 2; Yogyakarta: Gajah Madah University Press, 2013

Muhammad bin 'Isā bin Saurah bin Musā bin al-Dahhāk al-Tirmizìi, Sunan al-Tirmizì, Juz 3, h. 658.

Muhammad bin Ismā’ìl bin Șilah bin Muhammad al-Ḥasanī, Subul al-Salām Dār alHadis, t.t., t.th.), Juz I

Muhammad Suryani dkk., Lingkungan Sumber Daya Alam dan Kependudukan dalam Pembangunan Jakarta: UI-Press, 1987

Otto Sumarwoto, Ekologi Lingkungan Hidup dan pembangunan Cet. VII; Jakarta: Djambata, 1997

Yūsuf al-Qaradawi, Islam Agama Ramah Lingkungan. terj. Abdullah Hakam Shah, h. 83-85. 
Yusuf al-Qardhawi, Islam Ramah Lingkungan, diterjemahkan oleh Abdullah Hakam Jakarta: Pustaka Kautrsar, 2002 M 